\title{
Changes in live weight and biochemical blood indicators in Tyvan short-fat tailed sheep breed depending on the breeding zone and season of the year
}

\author{
Larisa Shimit ${ }^{1}$, Semyon Biltuev ${ }^{2}$, Vladimir Achituev ${ }^{2}$, Bair Zhamyanov ${ }^{2 *}$ and Zhanna \\ Mongush $^{3}$ \\ ${ }^{1}$ Tyva State University, Lenina st., bld. 36. Kyzyl, 667000, Republic of Tyva, Russian Federation \\ ${ }^{2}$ Buryat State Agricultural Academy named after V.R. Filippov, Pushkina st., bld. 8, Ulan-Ude, \\ 670034, Republic of Buryatia, Russian Federation \\ ${ }^{3}$ State Budgetary Sec of Tyva Rep. Tyva Agricultural Technical School, Druzhby st., bld. 2a, Kyzyl, \\ 667002, Republic of Tyva, Russian Federation
}

\begin{abstract}
The considers the research results of productive qualities and biological features of Tyvan short-fat tailed sheep breed depending on the season of the year and the breeding zone of the Republic of Tyva: mountain taiga-steppe, desert-steppe and dry steppe. The highest live weight was observed in sheep raised in the dry steppe zone. When studying the biochemical composition of the blood of sheep in the summer-autumn grazing period, the content in the blood of sheep of the compared groups of basic biochemical parameters is within the physiological norms. In the winter-spring period, when grazing sheep on rags of last year's grass due to a deficiency in their diets of basic nutrients, the blood levels of animals of all groups of total protein, calcium and reserve alkalinity are below physiological norms.
\end{abstract}

\section{Introduction}

For year-round pasture grazing in various natural and climatic zones of the Republic of Tyva, the main fodder for sheep is herbs of natural fodder land [1-6]. The most critical in the provision of animal feed is winter and early spring months, when the grass stand of pastures is represented by the herbs of last year's grass with insufficient content of nutrients required for their organisms. As a result, they have significant loss of live weight, which is restored during the brazing period on the green, succulent grass of summer-autumn pastures.

In the practice of sheep husbandry, the adaptive capabilities of animals to year-round pasture grazing are judged on their ability to recover winter losses of live weight in grazing on the nutrient-enriched grass stand of summer pastures [7-9].

Purpose of the study: The purpose of the study was to assess the productive and

\footnotetext{
*Corresponding author: bair1717@mail.ru
} 
biological features of Tyvan short-fat tailed sheep breed depending on the breeding zone and season of the year.

At the same time, the following tasks were solved:

- determine the change in the live weight of sheep depending on the breeding area and season of the year

- study biochemical indicators of sheep blood depending on the breeding zone and season of the year

\section{Materials and methods}

We have studied the adaptive properties of the Tyvan short-fat tailed sheep breed at year-round pasture grazing in MUE "Head Farm Torgalyg" in Ovyursky, MUE "Stud Farm Despen" in Tes-Khemsky and AC "Stud Farm Kyzylsky" in Kyzylsky cozhuuns, located respectively in Tannuol mountain taiga-steppe, Southern desert-steppe and Central Tyva dry-steppe zones of the Republic of Tyva. The object of research - purebred Tyvan sheep of gene pool farm and steppe type of this breed.

The live weight of sheep was determined in spring after wintering during the period of their valuation in April and autumn after graziery in October by individually weighing them on the scales with $0.5 \mathrm{~kg}$ accuracy.

The sheep blood content of total protein, calcium, phosphorus, reserve alkalinity was determined in autumn in October, in winter in December and in spring in March by laboratory method according to methodological guidelines of the AllRussian Scientific Research Institute for sheep and goat raising (1987).

\section{Research results}

Studies have shown differences in Tyvan short-fat tailed sheep in the living mass depending on their breeding area (table).

Table 1. Changes in the living mass of Tyvan short-fat tailed sheep according to breeding area and season of the year

\begin{tabular}{|c|c|c|c|c|c|c|}
\hline \multirow{2}{*}{ Indicator } & \multicolumn{6}{|c|}{ Breeding area of Tyvan short-fat tail sheep breed } \\
\cline { 2 - 7 } & $\begin{array}{c}\text { Tannuol mountain taiga- } \\
\text { steppe } \\
\text { (Group I) }\end{array}$ & \multicolumn{2}{c|}{$\begin{array}{c}\text { Southern desert-steppe } \\
\text { (Group II) }\end{array}$} & $\begin{array}{c}\text { Central Tyva dry steppe } \\
\text { (Group III) }\end{array}$ \\
\cline { 2 - 8 } & Stud rams & Ewes & Stud rams & Ewes & Stud rams & Ewes \\
\hline $\begin{array}{c}\text { Number of } \\
\text { animals }\end{array}$ & 102 & 252 & 117 & 289 & 131 & 311 \\
\hline Autumn & $69.5 \pm 0.17$ & $52.3 \pm 0.14$ & $78.2 \pm 0.28$ & $61.0 \pm 0.20$ & $82.5 \pm 0.28$ & $65.0 \pm 0.13$ \\
\hline Spring & $60.6 \pm 0.18$ & $43.0 \pm 0.14$ & $69.6 \pm 0.23$ & $52.5 \pm 0.19$ & $74.1 \pm 0.22$ & $56.7 \pm 0.13$ \\
\hline $\begin{array}{c}\text { Live weight } \\
\text { loss during the } \\
\text { wintering } \\
\text { period: }\end{array}$ & & & & & & \\
\hline kg & 8.9 & 9.3 & 8.6 & 8.5 & 8.4 & 8.3 \\
\hline$\%$ & 12.8 & 17.8 & 11.0 & 14.0 & 10.2 & 12.8 \\
\hline
\end{tabular}

The largest live weight is noted in Tyvan short-fat tail breed sheep bred in the dry steppe and the smallest - in the mountainous taiga-steppe zone. By this indicator, sheep of the desert-steppe zone occupied an intermediate position between the extreme options. Thus, stud rams and ewes of group III were superior in spring live weight over same gender 
analogues of group I by 13.5 and $13.7 \mathrm{~kg}$, or by $22.3-31.9 \%$ and in autumn -13.0 and 12.7 $\mathrm{kg}$, or by 18.7 and $24.3 \%$, II group - by 4.5 and $4.2 \mathrm{~kg}$, or 6.5 to $0.8 \%, 4.3$ and $4.0 \mathrm{~kg}$, or 5.5 to $6.5 \%$ respectively. Thus, the greatest loss of live weight during the wintering period is noted in Tyva short-fat tail sheep breed in the mountainous taiga-steppe zone $-12.8 \%$ in stud rams and $17.8 \%$ in ewes, or 2.6 and $5.0 \%$ more than that of the same gender analogues of the dry steppe and 1.8 and $3.8 \%$ of the steppe zone.

In case of year-round pasture grazing, depending on the season of the year, physiological changes occur in the animal body, which are interrelated with biochemical indicators of blood. According to the biochemical indicators of blood, it is possible to judge the intensity of metabolic processes and the productivity of animals in general (table 1,2,3).

Table 2. Biochemical blood indicators of Tyvan short-fat tail sheep according to season of year (autumn)

\begin{tabular}{|l|c|l|l|l|l|l|}
\hline \multirow{4}{*}{ Indicators } & \multicolumn{5}{|c|}{ Group } \\
\cline { 2 - 7 } & \multicolumn{2}{|c|}{$\mathrm{I}$} & \multicolumn{2}{c|}{ II } & \multicolumn{2}{c|}{ III } \\
\cline { 2 - 7 } & $\mathrm{St.ram}$ & Ewe & St.ram & Ewe & St.ram & Ewe \\
\cline { 2 - 7 } & $\mathrm{n}=10$ & $\mathrm{n}=10$ & $\mathrm{n}=10$ & $\mathrm{n}=10$ & $\mathrm{n}=10$ & $\mathrm{n}=10$ \\
\cline { 2 - 7 } & $\overline{(\mathrm{X} \pm \mathrm{S} \overline{\mathrm{x}})}$ & $\overline{(\mathrm{X} \pm \mathrm{S} \overline{\mathrm{x}})}$ & $\overline{(\mathrm{X} \pm \mathrm{S} \overline{\mathrm{x}})}$ & $\overline{(\mathrm{X} \pm \mathrm{S} \overline{\mathrm{x}})}$ & $\overline{(\mathrm{X} \pm \mathrm{S} \overline{\mathrm{x}})}$ & $\overline{(\mathrm{X} \pm \mathrm{S} \overline{\mathrm{x}})}$ \\
\hline $\begin{array}{l}\text { total protein, g. } \\
\%\end{array}$ & $6.9 \pm 0.13$ & $6.5 \pm 0.24$ & $7.3 \pm 0.26$ & $6.8 \pm 0.14$ & $7.6 \pm 0.20$ & $7.3 \pm 0.40$ \\
\hline $\begin{array}{l}\text { total calcium, } \\
\text { mg. \% }\end{array}$ & $10.8 \pm 0.35$ & $10.2 \pm 0.18$ & $11.5 \pm 0.25$ & $10.5 \pm 0.42$ & $12.2 \pm 0.34$ & $11.0 \pm 0.43$ \\
\hline $\begin{array}{l}\text { reserve } \\
\text { alkalinity, } \mathrm{t} \% \\
\mathrm{CO}_{2}\end{array}$ & $51.6 \pm 0.41$ & $49.0 \pm 0.43$ & $55.6 \pm 0.40$ & $52.3 \pm 0.62$ & $61.7 \pm 0.54$ & $58.8 \pm 0.42$ \\
\hline $\begin{array}{l}\text { phosphorus } \\
\text { inorganic, mg. } \\
\%\end{array}$ & $5.2 \pm 0.40$ & $4.3 \pm 0.13$ & $5.8 \pm 0.23$ & $5.4 \pm 0.32$ & $6.8 \pm 0.18$ & $6.2 \pm 0.13$ \\
\hline
\end{tabular}

When studying the biochemical composition of sheep's blood in the autumn period, it was established that in general all indicators were within the norm. This shows that all sheep are clinically healthy and received a full diet of grazing grass. During summerautumn period with pasture grazing, the amount of total protein, phosphorus, calcium, reserve alkalinity increases in animal blood. The most important indicator that determines the level of protein nutrition is the total protein in blood. The level of this indicator in the sheep blood in the autumn period is within the norm $6.5-7.6 \%$ at the norm $6.0-7.5 \%$. Calcium is the main element in the structure of bone tissue, blood, nervous and muscle tissue. The content of total calcium - 10.2-12.2\% and phosphorus - $4.5-6.5 \%$, as well as calcium were within the physiological norm. Reserve alkalinity - the indicator of acid-base ratio were also within the normative indicators of $49.0-61.7 \%$ in the body of the animals compared.

During winter, biochemical blood indicators in stud rams of all groups were also within physiological norms except for reserve alkalinity. Reserve alkalinity in group I animals was below the physiological norm by $3.0 \%$, group II by $2.6 \%$ and group III by $0.2 \%$.

Table 3. Biochemical blood indicators of Tyvan short-fat tail sheep according to season (winter)

\begin{tabular}{|c|c|c|c|c|c|c|}
\hline \multirow{5}{*}{ Indicators } & \multicolumn{6}{|c|}{ Group } \\
\hline & \multicolumn{2}{|c|}{ I } & \multicolumn{2}{|c|}{ II } & \multicolumn{2}{|c|}{ III } \\
\hline & St.ram & Ewe & St.ram & Ewe & St.ram & Ewe \\
\hline & $\mathrm{n}=10$ & $\mathrm{n}=10$ & $\mathrm{n}=10$ & $\mathrm{n}=10$ & $\mathrm{n}=10$ & $\mathrm{n}=10$ \\
\hline & $\left.\overline{(X} \pm S^{x}\right)$ & $\left.\overline{(X} \pm S^{-}\right)$ & $\left.\overline{(X} \pm S_{\bar{x}}\right)$ & $\left.\overline{(X} \pm S^{-x}\right)$ & $\left.\overline{(X} \pm S^{-}\right)$ & $\left.\overline{(X} \pm S_{x} \bar{x}\right)$ \\
\hline
\end{tabular}




\begin{tabular}{|l|l|l|l|l|l|l|}
\hline $\begin{array}{l}\text { total protein, g. } \\
\%\end{array}$ & $6.5 \pm 0.22$ & $5.3 \pm 0.22$ & $6.8 \pm 0.27$ & $5.5 \pm 0.27$ & $7.0 \pm 0.18$ & $5.8 \pm 0.16$ \\
\hline $\begin{array}{l}\text { total calcium, } \\
\text { mg. } \%\end{array}$ & $10.1 \pm 0.39$ & $7.0 \pm 0.38$ & $10.7 \pm 0.51$ & $7.7 \pm 0.21$ & $11.0 \pm 0.39$ & $8.3 \pm 0.27$ \\
\hline $\begin{array}{l}\text { reserve } \\
\text { alkalinity, } \mathrm{t} \% \\
\mathrm{CO}_{2}\end{array}$ & $45.0 \pm 0.34$ & $40.7 \pm 0.30$ & $45.4 \pm 0.48$ & $42.7 \pm 0.31$ & $47.8 \pm 0.41$ & $45.3 \pm 0.28$ \\
\hline $\begin{array}{l}\text { phosphorus } \\
\text { inorganic, } \mathrm{mg} . \\
\%\end{array}$ & $5.6 \pm 0.39$ & $5.0 \pm 0.20$ & $6.2 \pm 0.18$ & $5.8 \pm 0.30$ & $7.1 \pm 0.19$ & $6.0 \pm 0.25$ \\
\hline
\end{tabular}

In ewes of all groups, the blood content of the total protein was lower than physiological standards by $0.2-0.7 \%$, calcium by $1.7-3.0 \%$ and reserve alkalinity by $2.7-$ $7.3 \%$. At the same time, lower indicators of these elements are noted in group I ewes.

Table 4. Biochemical blood indicators of Tyvan short-fat tail sheep according to season of year (spring)

\begin{tabular}{|l|c|c|c|c|c|c|}
\hline \multirow{2}{*}{ Indicators } & \multicolumn{5}{|c|}{ Group } \\
\cline { 2 - 7 } & \multicolumn{2}{|c|}{ I } & \multicolumn{2}{c|}{ II } & \multicolumn{2}{c|}{ III } \\
\cline { 2 - 7 } & St.ram & Ewe & St.ram & Ewe & St.ram & Ewe \\
\cline { 2 - 7 } & $\mathrm{n}=10$ & $\mathrm{n}=10$ & $\mathrm{n}=10$ & $\mathrm{n}=10$ & $\mathrm{n}=10$ & $\mathrm{n}=10$ \\
\cline { 2 - 7 } & $\overline{(\mathrm{X} \pm \mathrm{S} \overline{\mathrm{x}})}$ & $\overline{(\mathrm{X} \pm \mathrm{S} \overline{\mathrm{x}})}$ & $\overline{(\mathrm{X} \pm \mathrm{S} \overline{\mathrm{x}})}$ & $\overline{(\mathrm{X} \pm \mathrm{S} \overline{\mathrm{x}})}$ & $\overline{(\mathrm{X} \pm \mathrm{S} \overline{\mathrm{x}})}$ & $\overline{(\mathrm{X} \pm \mathrm{S} \overline{\mathrm{x}})}$ \\
\hline $\begin{array}{l}\text { total protein, g. } \\
\%\end{array}$ & $6.4 \pm 0.18$ & $6.2 \pm 0.22$ & $6.9 \pm 0.20$ & $6.5 \pm 0.20$ & $7.2 \pm 0.13$ & $6.8 \pm 0.20$ \\
\hline $\begin{array}{l}\text { total calcium, } \\
\text { mg. \% }\end{array}$ & $10.0 \pm 0.41$ & $7.4 \pm 0.15$ & $10.1 \pm 0.27$ & $8.0 \pm 0.30$ & $10.8 \pm 0.24$ & $9.3 \pm 0.28$ \\
\hline $\begin{array}{l}\text { reserve } \\
\text { alkalinity, } \mathrm{t} \% \\
\text { CO }\end{array}$ & $40.8 \pm 0.51$ & $37.4 \pm 0.47$ & $42.1 \pm 0.32$ & $39.5 \pm 0.33$ & $45.2 \pm 0.33$ & $43.2 \pm 0.26$ \\
\hline $\begin{array}{l}\text { phosphorus } \\
\text { inorganic, mg. } \\
\%\end{array}$ & $4.8 \pm 0.21$ & $4.2 \pm 0.13$ & $5.6 \pm 0.20$ & $5.0 \pm 0.18$ & $6.0 \pm 0.10$ & $5.7 \pm 0.28$ \\
\hline
\end{tabular}

In the spring, ewes' blood content of the total protein rose to the level of physiological norms, apparently due to feeding them with concentrated feed and hay. During this period, the inclusion of additional grazing grass into the diet of ewes in the form of prepared feed addition affected the increase of total calcium in the blood content. However, the rate of its content, especially in animals in group I, was lower than physiological norms.

In stud rams and ewes of all groups during winter and spring periods, the index of acidbase ratio in the body (reserve alkalinity) was lower than physiological norms.

This is apparently due to the increasing tension occurring in the animal body, physiological processes associated with the lowering of ambient temperature in winter and increasing frequency of winds in the spring.

\section{Conclusion}

The largest live weight is noted in Tyvan short-fat tail breed sheep bred in the dry steppe and the smallest - in the mountainous taiga-steppe zone. By this indicator, sheep of the desert-steppe zone occupied an intermediate position between the extreme options. Thus, stud rams and ewes of group III were superior in spring live weight of gender analogues of group I by 13.5 and $13.7 \mathrm{~kg}$, or by $22.3-31.9 \%$ and in autumn -13.0 and 12.7 
$\mathrm{kg}$, or by 18.7 and $24.3 \%$, II group - by 4.5 and $4.2 \mathrm{~kg}$, or 6.5 to $0.8 \%, 4.3$ and $4.0 \mathrm{~kg}$, or 5.5 to $6.5 \%$, respectively. The greatest loss of live weight during the wintering period was observed in the sheep of the Tyvan short-fat tail breed in the mountain taiga-steppe zone $12.8-17.8 \%$, or 2,6 and $5.0 \%$ more than in gender analogues of the dry steppe and 1.8 and $3.8 \%$ of the desert-steppe zone.

In the summer-autumn pastoral period, which is the most favorable in feed supply, the basic biochemical indicators in sheep blood content of compared groups is within the limits of physiological norms. In the winter and spring period, when sheep grazing on the last year's grassland litter, due to basic nutrients deficiency in their diets such indicators as total protein, calcium and reserve alkalinity is below physiological norms in blood samples of animals of all groups. At the same time, the greatest decrease of these indicators was observed in sheep of the mountainous taiga-steppe zone.

\section{References}

1. H.A. Amerkhanov et.al, Exterior constitutional and productive features of different types of Tyvan short-fat tailed sheep, 90 (M.: RSAU — MAA named after. K.A. Timiryazev, 2010)

2. S.I. Biltuev, Creation of the type and breed of sheep in specific environmental conditions of Western Siberia and the Republic of Buryatia, 239 (Publishing house of BSAA named after V.R. Filippov, 2010)

3. M.D. Chamukha, Peculiarities of breed formation in sheep breeding in areas with specific natural climatic conditions, 284 (RAAS (Sib. Division). Sib.n Research and Planning Institute of livestock. Novosibirsk, 2004)

4. A.A. Gorshkova, L.T. Mongush, Steppe pastures of Central Tyva, 42 (Kyzyl, 1992)

5. P.I. Kravchenko, B.B. Balchir, et. al Natural and economic conditions, state and prospects of livestock development. Methodological recommendations, Zonal systems of animal husbandry of the Tyva, ASSR, 6 (Novosibirsk, 1989)

6. S.S. Kurbatskaya, V.I. Kanzai, S.G. Kurbatskaya, Recommendations on agriculture adaptation of the Republic of Tyva to climate change, 39-41 (Krasnoyarsk, 2011)

7. P.A. Parsons, Biol. Rev. Camb. Philos. Soc, 80 (4), 589-610 (2005)

8. E.A. Tansey, C.D. Johnson, Adv. Physiol. Educ, 39 (3), 139-148 (2015) doi 10.1152/advan.00126.2014

9. J. Hammond, J. Agr. Shi, 34 (1944) 